\title{
Socioeconomic and Demographic Profile of Children and Adolescents with Chronic Disease: Integrative Literature Review

Thalita Nóbrega Mendes ${ }^{1}$, Raquel Ferreira Sá ${ }^{2}$, Yana Balduino de Araújo ${ }^{3}$, Sérgio Ribeiro dos Santos ${ }^{4}$, João Agnaldo Nascimento ${ }^{5}$, Camilla Melo da Costa ${ }^{6}$, Érika Leite da Silva Cardoso7, Evyllâne Matias Veloso Ferreira7, Nívea Trindade de Araújo Tiburtino Neves ${ }^{8}$, Laura Cristhiane Mendonça Rezende Chaves ${ }^{9}$

\section{Abstract}

Objective: to analyze the scientific literature about the socioeconomic profile of children and adolescents with chronic disease.

Method: This is an integrative literature review held from October 2015 to April 2016, through the virtual libraries LILACS, PUBMED and SciELO considering published studies in Spanish, English or Portuguese languages, using the following keywords: children; adolescent; chronic disease; chronic illness, factors socioeconomics.

Results: were selected and analyzed 18 articles that meet the inclusion criteria of this study. It was noted that the scientific publications describe the demographic profile and social and economic variables of children and adolescents with chronic diseases, in a secondary manner, based on a specific chronic disease.

Conclusion: its relevant and necessary consider to describe in detail the socioeconomic profile of children and adolescents with chronic diseases so that other elements such as risk and social vulnerability can be included in the integral care process to this clientele.
1 Medicine student of the Federal University of Paraiba. João Pessoa, Paraiba, Brazil.

2 Physiotherapy student of the Federal University of Paraiba. João Pessoa, Paraiba, Brazil.

3 Nursing. Doctoral student program in Decision Models, Federal University of Paraiba. Joao Pessoa, Paraiba, Brazil.

4 Nurse. Doctor in Sociology. Titular teacher Department of Clinical Nursing UFPB. Teacher of the Graduate Program in Health Decision Models. GEPAIE Leader.

5 Teacher of the Department of Statistics, Federal University of Paraiba. Joao Pessoa, Paraiba, Brazil.

6 Nursing student of the Federal University of Paraiba. João Pessoa, Paraiba, Brazil.

7 Nursing.Federal University of Paraiba. João Pessoa, Paraiba, Brazil.

8 Nursing. Master student program in Decision Models, Federal University of Paraiba. Joao Pessoa, Paraiba, Brazil.

9 Master of Nursing, Federal University of Paraiba. João Pessoa, Paraiba, Brazil.

\section{Contact information:}

Yana Balduino de Araújo.

Address: Program in Decision Models, Federal University of Paraiba. Joao Pessoa, Paraiba, Brazil.

Tel: (+55) 0839988280303.

”yanabalduino@gmail.com

\section{Keywords}

Children; Adolescent; Chronic Disease; Chronic Illness, Factors

Socioeconomics. 


\section{Introduction}

Many developing countries have experienced a demographic transition, characterized by falling in the mortality and birth rates, combined with increased life expectancy. This change was due to the reduction of premature deaths and reducing child mortality, reflected by the improvement of the population's quality of life, the advancement of medical technology, the creation of public health programs, access to basic sanitation and improved personal hygiene [1, 2].

In this sense, with the control of infectious diseases, there have been changes in the profile of morbidities in society and therefore people's living conditions began to be determined mainly by issues related to external factors (environmental, social, economic, habits and lifestyle) [3]. This reality causes changes in the health-disease, which trend of acute and infectious diseases shall be replaced by chronic diseases, thus characterizing the current reality of the epidemiological transition.

According to the World Health Organization (WHO), chronic diseases are defined as diseases that have extended time to their complete installation, with origin at young ages, and in a greater proportion, influenced by the individual living conditions. More specifically, in children and adolescents, chronic diseases are conditions with durability of three months or more, which interfere with the routine of the same, may cause hospitalizations for more than a month [4].

Basically, diseases are divided between communicable and non-communicable chronic diseases. This form of division is widely used in epidemiology. Therefore, it is not as favorable now to link them with health care systems, since certain communicable and acute diseases, which have long life (HIV/ AIDS, Tuberculosis, Leprosy), are classified as chronic diseases. Furthermore, it excludes other pathophysiological conditions that are not disease, but are chronic. With this, a new categorization emerged, developed by theoreticians linked to the chronic care model and recognized by the WHO: acute and chronic conditions [2].

Chronic conditions lead to many symptoms and tend to reduce the individual's quality of life, as its duration is long, more than three months, and in some cases they present their selfies definitively and permanently. Generate a vicious cycle of symptoms, causing a muscular tension that leads to pain, stress and anxiety, causing emotional problems, which leads to fatigue and feeds the chronic condition [2]. In this perspective, chronic diseases include noncommunicable diseases, persistent communicable, long-term mental disorders and continuous physical/structural disabilities.

Various types of chronic diseases are discovered or developed in childhood, interfering in the family universe, requiring family members of a medical, social and psychological assistance. This interference may cause implications for the quality of life of all family [5].

With this, the whole family is mobilized so can get the treatment and proper care. Sometimes this condition causes stress, overload, anxiety and changes in family routine, shaking thus the structure, relationship and family dynamics. It is known, however, that a good family life is directly related to the quality of life and well-being of children/adolescents with chronic disease, since a good family functioning, comprehend a good adaptation and disease confrontation $[6,7]$.

Having a child/adolescent with chronic illness in the family environment, by itself, comprehend an overload on the family, but the management of this condition is linked to several factors, among them, have socioeconomic (family income, education level, employment status, among others). Studies show that lower socioeconomic levels have negatively interfered in family functioning, bringing results as marital conflict, parental stress, difficulties of managing the disease because of limited resources to purchase medications, access to health services; as well as the family's education 
level, influencing the prevention and management of crises [6-8].

Taking the context above into account, it is observed that many social and economic factors can influence the emergence and maintenance of chronic diseases. Nonetheless, several of them can be prevented and controlled, however, one needs to know what these factors are and how to interfere, so that can be able to intervene and understand the problem more fully and effectively. In this sense, it is important to trace the socioeconomic profile that characterizes children/adolescents with chronic diseases in health services, in order to develop strategies based on the needs of each family and to provide a more targeted and qualified care to all involved in the health-disease.

Therefore, this study aims to analyze the scientific literature on the socioeconomic profile of children and adolescents with chronic disease, in order to support reflection and improvement of health strategies.

\section{Methods}

This is an integrative literature review conducted in virtual libraries Latin American and Caribbean Social and Health Sciences (LILACS), National Library of Medicine (PubMed) and Scientific Electronic Library Online (SciELO), from October 2015 to April 2016.

Were used the descriptors combined to proceed the searches in the bases: chidren; adolescent; chronic disease; chronic illness, socioeconomics factors, all considered as descriptors in the DECs and MESH. Was applied to the result of the base, publications of the last 10 years (2005-2015), and the languages English, Portuguese and Spanish, as well as the availability of access to the summary/abstract. The main question adopted for this study was: what was produced in the scientific literature on the socioeconomic profile of children and/or adolescents with chronic disease?
Inclusion criteria were: to contain as subject of study questions about the description of the socioeconomic profile of children and/or adolescents with chronic disease as the main theme of the study; scientific articles or other research published in the languages mentioned above. Exclusion criteria: studies that did not meet at least one of the criteria of inclusion, articles repeated between the bases and the different languages chosen for the study.

The search strategy followed the steps outlined in Figure $\mathbf{1}$ and 2. To operationalize the summarization of the final stage studies of the integrative review, just as well the evaluation and interpretation of results and synthesis of knowledge, built up a script-instrument consists of the following fields: article title, author, year of publication, language, database, site of study development, study type, objective, methodological characteristics, main aspects of data analysis, relevant results and major contributions.

To give a clear and objective analysis of the results of this study, it was decided to group the findings into two groups: Relations between demographic variables (race, color, age, country or region and ethnicity) and chronic illness in children and adolescents; and relations between social and economic variables (income, occupation, data on family, education and primary caregiver) and chronic illness in children and adolescents.

\section{Results}

When using the descriptors combined with each other to the database searches, were found 3.083 scientific productions. After considering the inclusion and exclusion criteria, remaining 292 articles. After careful reading of this production, only 18 articles fulfill the objectives of this study. The results of scientific production that comprised the final sample, as the title, author, periodical and country where it developed can be seen in the table below, Table 1. 
Figure 1: Explanatory flowchart search strategy and selection of studies in the LILACS, 2016.

\section{Database: LILACS}

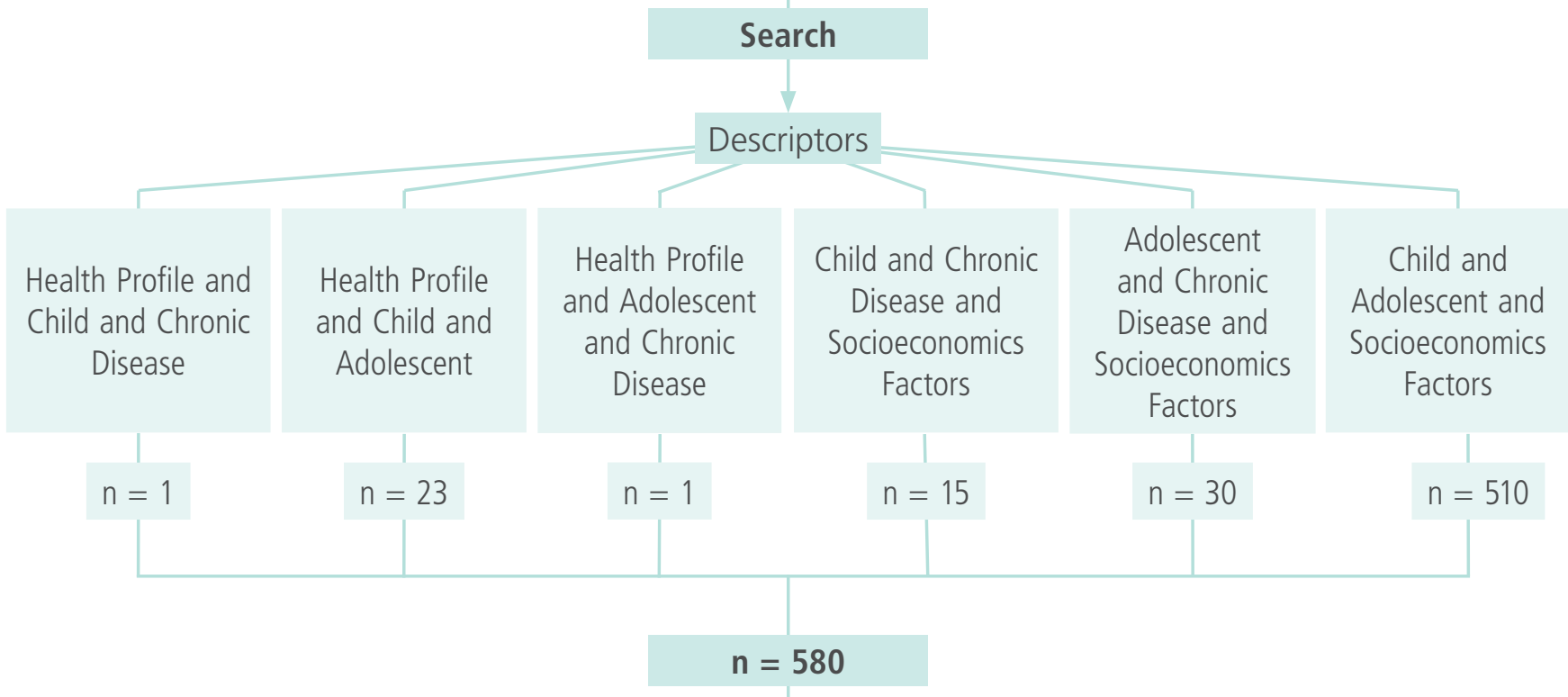

\section{Application of Criteria}

\section{Inclusion}

Contain as subject of study questions about the description of the socioeconomic profile of children and / or adolescents with chronic disease as the main theme of the study; scientific articles or other research published in Portuguese, English and Spanish and in the range 2005-2015.

\section{Exclusion}

Studies that do not meet at least one of the criteria for inclusion, articles repeated between the bases and the different languages chosen for the study.

\section{Resulted in: 485 excluded}

\section{Resulted in: 95 articles included \\ Reading the title, introduction, objective and methodology}


Figure 2: Explanatory flowchart search strategy and selection of studies in the PubMed, $2016 .$.

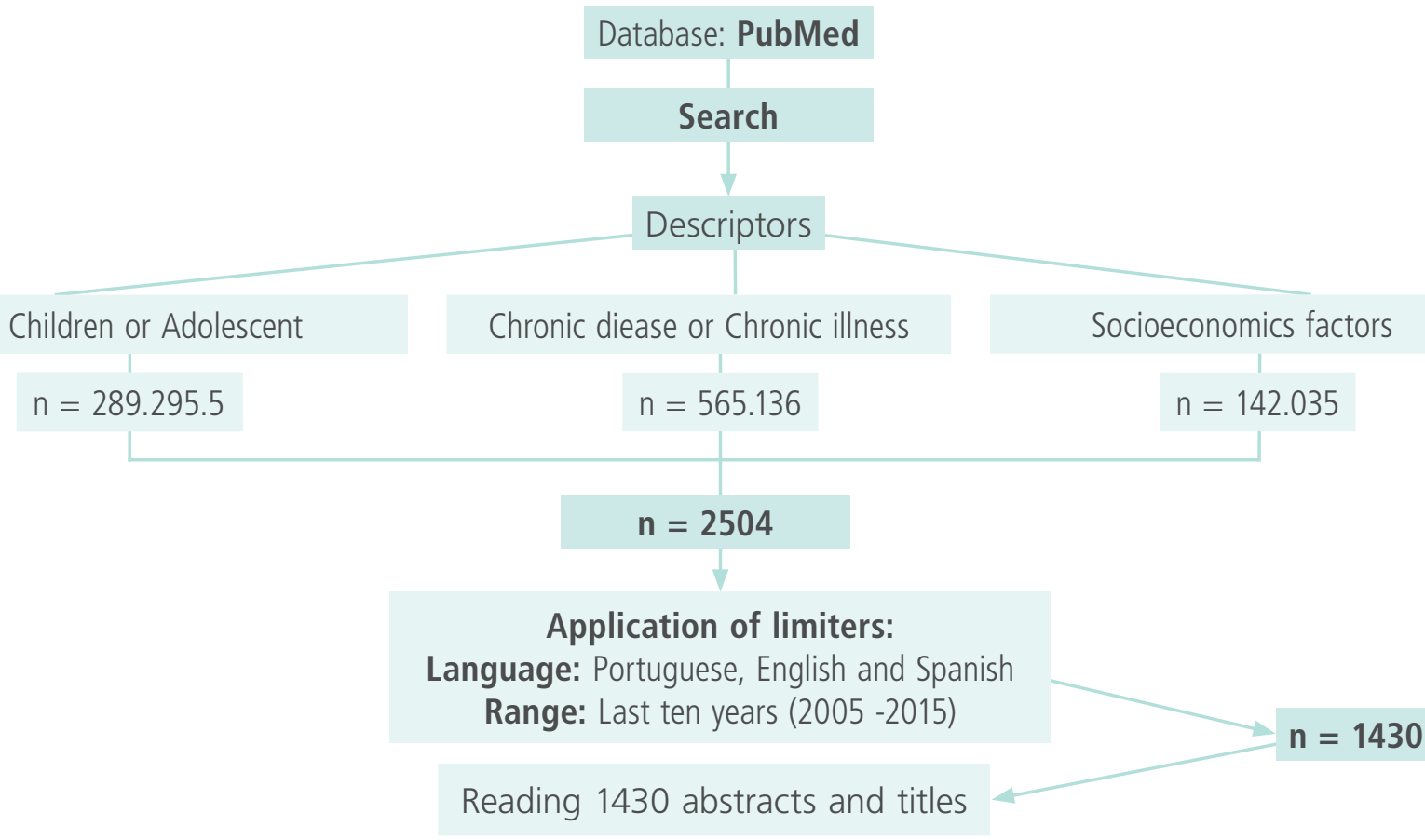

\section{Application of Criteria}

\section{Inclusion}

Contain as subject of study questions about the description of the socioeconomic profile of children and / or adolescents with chronic disease as the main theme of the study; scientific articles or other research published in the aforementioned languages and in the range 2005-2015.

Resulted in: 198 articles included

Reading the title, introduction, objective and methodology

Application of Inclusion and Exclusion Criteria

Resulted in:

166 excluded
Resulted in:

32 included
Read in full and completing the review of the script

\section{Exclusion}

Studies that do not meet at least one of the criteria for inclusion, articles repeated between the bases and the different languages chosen for the study.

\section{Resulted in: 1232 excluded}

Review Final Sample: 15 
Table 1. Distribution of studies on the title, authors, journal and country. Joao Pessoa, 2016.

\begin{tabular}{|c|c|c|c|}
\hline Title & Authors & $\begin{array}{l}\text { Periodical } \\
\text { (year, Vol., No., pp.) }\end{array}$ & $\begin{array}{l}\text { Country where } \\
\text { the study was } \\
\text { conducted }\end{array}$ \\
\hline $\begin{array}{l}\text { Income level and kidney disease severity and progression among children } \\
\text { and adolescents with CKD: a report from the Chronic Kidney Disease in } \\
\text { Children (CKiD) Study }\end{array}$ & $\begin{array}{l}\text { Hidalgo G, Ng DK, Mins MM, Minnick, Hansen TB, } \\
\text { Warady BA, Furth S. }\end{array}$ & $\begin{array}{l}\text { Am J Kidney Dis. 2013; } \\
\text { 62(6):1087-94. }\end{array}$ & $\begin{array}{l}\text { Estados Unidos - } \\
\text { Canadá }\end{array}$ \\
\hline $\begin{array}{l}\text { The quality of life of Brazilian adolescents with asthma: associated clinical } \\
\text { and sociodemographic factors }\end{array}$ & Amaral LM, Moratelli L, Palma PV, Leite ICG. & J Asthma 2014; 51: 660-6. & Brasil \\
\hline $\begin{array}{l}\text { Silverstein and WFB Prevalence of and Disparities in Barriers to Care } \\
\text { Experienced by Youth with Type } 1 \text { Diabetes }\end{array}$ & $\begin{array}{l}\text { Valenzuela JM, Seid M, Waitzfelder B, Anderson AM, } \\
\text { Beavers DP, Dabelea DM, et al. }\end{array}$ & $\begin{array}{l}\text { J Pediatr 2014; 164(6):1369- } \\
1375 .\end{array}$ & Estados Unidos \\
\hline $\begin{array}{l}\text { Health of adolescents: a population-based study in Campinas, São Paulo, } \\
\text { Brazil }\end{array}$ & Braz M, Barros Filho AA, Barros MBA. & $\begin{array}{l}\text { Cad. Saúde Pública 2013; } \\
\text { 29(9): 1877-1888. }\end{array}$ & Brasil \\
\hline $\begin{array}{l}\text { Analysis of the impact of environmental and social factors, with a } \\
\text { particular emphasis on education, on the level of metabolic control in type } \\
1 \text { diabetes in children. }\end{array}$ & Stefanowicz A, Birkholz D, Mysliwiec M. & $\begin{array}{l}\text { Endokrynolgia Polska/Polish } \\
\text { Journal of Endocrunology } \\
2012 ; 63 \text { (1): 34-41. }\end{array}$ & Polônia \\
\hline Asthma and the Achievement Gap Among Urban Minority Youth & Basch CE. & $\begin{array}{l}\text { Journal os School Health } \\
\text { 2011; 81(10): 606-613. }\end{array}$ & Estados Unidos \\
\hline $\begin{array}{l}\text { Association of Socioeconomic Status with the Use of Chronic Therapies } \\
\text { and Healthcare Utilization in Children with Cystic Fibrosis }\end{array}$ & $\begin{array}{l}\text { Schechter MS, McColley SA, Silva S, Haselkorn T, } \\
\text { Konstan MW, Wagener JS. }\end{array}$ & $\begin{array}{l}\text { J Pediatr. 2009; 155(5): } \\
\text { 634-9. }\end{array}$ & $\begin{array}{l}\text { Estados Unidos - } \\
\text { Canadá }\end{array}$ \\
\hline Family Functioning in the Context of Pediatric Chronic Conditions & $\begin{array}{l}\text { Herzer M, Godwala N, Hommel KA, Driscoll K, } \\
\text { Mitchell M, Crosby LE et al. }\end{array}$ & $\begin{array}{l}\text { J Dev Behav Pediatr. 2010; } \\
\text { 31(1): } 26 .\end{array}$ & Estados Unidos \\
\hline $\begin{array}{l}\text { Incidence of first primary central nervous system tumors in California, } \\
\text { 2001-2005: children, adolescents and teens }\end{array}$ & Brown M, Schrot R, Bauer K, Dodge J. & $\begin{array}{l}\text { J Neurooncol. 2009; 94(2): } \\
\text { 2637-3. }\end{array}$ & Estados Unidos \\
\hline $\begin{array}{l}\text { Health-related quality of life of children with mild to moderate chronic } \\
\text { kidney disease }\end{array}$ & $\begin{array}{l}\text { Gerson AC, Wentz A, Abraham AG, Mendley SR, } \\
\text { Hooper SR, Butler RW et al. }\end{array}$ & $\begin{array}{l}\text { Pediatrics. 2010; 125(2): } \\
\text { e349-e357. }\end{array}$ & Estados Unidos \\
\hline Family functioning and juvenile chronic physical illness in Northern Russia & Zashikhina A and Hagglof B & $\begin{array}{l}\text { Acta Paediatrica 2009; } 98 \text { : } \\
\text { 355-522. }\end{array}$ & Norte da Rússia \\
\hline
\end{tabular}




\section{Title}

Mental, Emotional, and Social Problems

Among School Children with Asthma

The Role of Parent Health Literacy Among Urban Children with Persistent Asthma

Clinical and demographic risk factors associated with chronic suppurative otitis media

Markers of CKD Aboriginal and nonAboriginal children. Early chronic kidney disease in Aboriginal and non-Aboriginal Australian children: remoteness, socioeconomic disadvantage or race?

Socioeconomic status and inflammatory processes in childhood asthma: The role of psychological stress

Quality of life and socio-economic aspects in Diabetics TYPE 1

\section{Authors}

Collins JE, Gill TK, Chittleborough CR, Martin J, Taylor AW, Winefield H.

Shone LP, Conn KM, Sanders L \& Halterman JS.

Akeem OL, Fatai AO, Sufyan AM, Ismail AA, Kehinde GA, Taiwo JL, Zainab OI, Taofeeq OY, Oladapo O

\section{Haysom et al.}

Chen et al.

J Allergy Clin Immunol Canadá 2006; 117(5).

Araujo AF, Souza MEA e Menezes CA.

\section{Periodical \\ (year, Vol., No., pp.)}

Country where the study was conducted

Journal os Asthma 2008; 45(6): 489-493.

Patient Education and Estados Unidos Counseling 2009; 75(3): 368-375

International Nigéria Journal of Pediatric Otorhinolaygology 2007; 71: 1549-1554.

Kidney International Austrália 2007; 71: 787-794.
Austrália do Sul

\section{Austrália}

1124-1130.

Source: Research data, 2016

In Table 2 are expressed the main results presented by articles in the sample of this integrative review. The findings were characterized as the study setting, study chronic disease and sociodemographic information of children and adolescents with such chronic disease.

The selected sample, 18 articles described about the demographic profile of children and/or adolescents with chronic illness and their families. During the analysis, there are no studies that aimed to provide a description of the general demographic profile of children and adolescents with chronic diseases, but studies that addressed the description of this secondarily profile based on a particular chronic disease.

It is observed in Table 2, the demographic data of children and adolescents with chronic diseases, highlighted by studies, emphasized the following di-

Table 2. Description of the socio-demographic profile of children and adolescents with chronic diseases according to the selected items..

\begin{tabular}{|c|c|c|c|c|}
\hline $\begin{array}{c}\text { No } \\
\text { Article }\end{array}$ & Reference & Study Of Scenery & Chronic Disease & Sociodemographic Data \\
\hline 1 & [8] & $\begin{array}{l}\text { Multicenter study in the } \\
\text { USA and Canada }\end{array}$ & Chronic Kidney Disease & $\begin{array}{l}\text { Low income; black race; Hispanic ethnicity; and } \\
\text { Female }\end{array}$ \\
\hline 2 & {$[11]$} & Brazil & Asthma & Children under 15; male \\
\hline 3 & {$[14]$} & Goiânia, Goiás, Brazil & Diabetes Mellitus Type I & Average age at 10 years \\
\hline 4 & [16] & Florida, USA & Diabetes Mellitus Type I & Non-Hispanic black young \\
\hline 5 & [3] & São Paulo, Brazil & $\begin{array}{l}\text { Asthma, heart disease, } \\
\text { diabetes, among others. }\end{array}$ & Affect younger in age from 15 to 19 years \\
\hline
\end{tabular}




\begin{tabular}{|c|c|c|c|c|}
\hline $\begin{array}{l}\text { No } \\
\text { Article }\end{array}$ & Reference & Study Of Scenery & Chronic Disease & Sociodemographic Data \\
\hline 6 & [15] & Poland & $\begin{array}{l}\text { Diabetes Mellitus Type I } \\
\text { decompensated }\end{array}$ & Highest rate between 13 and 18 years old \\
\hline 7 & [10] & Puerto Rico & Asthma & $\begin{array}{l}\text { Black children; poor young; residents in urban } \\
\text { area }\end{array}$ \\
\hline 8 & [19] & $\begin{array}{l}\text { Multicenter study in the } \\
\text { USA and Canada }\end{array}$ & Cystic fibrosis & $\begin{array}{l}\text { Low income; low maternal education; less } \\
\text { access to medical appointments }\end{array}$ \\
\hline \multirow[t]{4}{*}{9} & \multirow[t]{4}{*}{ [6] } & \multirow[t]{4}{*}{ United States } & Cystic fibrosis & Average 12 year old, Female; White color; \\
\hline & & & Obesity & Average 9 years, Female and black color \\
\hline & & & Sickle Cell anemia & Average of 10 years and black color \\
\hline & & & Epilepsy & Male gender, white; average age of 8 years \\
\hline 10 & [17] & California, United States & Cancer & Male children; less than 5 years; Hispanic \\
\hline 11 & [21] & United States & Chronic Kidney Disease & $\begin{array}{l}\text { Male average of } 7 \text { years with chronic disease; } \\
\text { minor physical conditions, low education and } \\
\text { emotional conditions }\end{array}$ \\
\hline 12 & [7] & Northern Russia & $\begin{array}{l}\text { Diabetes, Asthma and } \\
\text { Epilepsy }\end{array}$ & Difficulties encountered in single-parent families \\
\hline 13 & [12] & South Australia & Asthma & Male; 5 to 15 years of age \\
\hline 14 & [22] & Rochester, New York & Asthma & $\begin{array}{l}\text { Average age of } 7 \text { years; Hispanic father; public } \\
\text { health insurance; low health knowledge of } \\
\text { parents }\end{array}$ \\
\hline 15 & [18] & Nigeria & Otitis Media & $\begin{array}{l}\text { Children with a large number of residents in the } \\
\text { same house; family with } 5 \text { children }\end{array}$ \\
\hline 16 & [9] & Australia & Chronic Kidney Disease & Aboriginals; male; average age of 8.9 years \\
\hline 17 & [20] & Vancouver, Canada & Asthma & $\begin{array}{l}\text { Lower socioeconomic conditions; High stress } \\
\text { perception and threatens }\end{array}$ \\
\hline 18 & [13] & Itabuna, Bahia, Brazil & Diabetes Mellitus Type I & $\begin{array}{l}\text { Female; per capita family income of } 0.70 \\
\text { minimum wages; elementary School. }\end{array}$ \\
\hline
\end{tabular}

Source: Research data, 2016

seases: Chronic Kidney Disease, Asthma, Diabetes Mellitus Type I, Cystic Fibrosis, Obesity, Sickle Cell Anemia, Cancer, epilepsy and otitis media.

\section{Discussion}

From the findings the authors organized the discussion into two categories:relations between demographic variables (race, color and sex) and relations between social and economic variables (income, occupation, data on family, education and primary caregiver) and chronic disease in children and adolescents.
Relations between demographic variables (race, color and sex) and chronic illness in children and adolescents

It is important to highlight a study conducted in 2008 in the city of São Paulo which collected demographic data of 995 adolescents with chronic diseases, which were: asthma/bronchitis/emphysema, heart disease, circulation problems, diabetes, hypertension, tendinitis/RSI/WRMD and rheumatism/arthritis/osteoarthritis. The data showed that this population had the same percentage of female and male and white sexes (65.28\%). Also showed that among adolescents, the prevalence of chronic diseases is $19.17 \%$ and that young people aged bet- 
ween 15 to 19 years are 1.38 times more likely to have chronic disease than those in the age group of 10 to 14 years [3].

In one of the study, Demographic data (gender, age and color) and this relation with the prevalence of five chronic conditions including: cystic fibrosis, obesity, sickle cell anemia, inflammatory bowel disease and epilepsy, was the target of a study. The first condition studied, showed an average in children of about 12 years old with more cases in females and white. With regard to obesity, the research highlights the average age of 9 years, more present in female and majority black. In sickle cell anemia, the mean age was 10 years, there was no difference between genders and all participants were black. In the inflammatory bowel disease, most of them were white, with most of the male index and average of 15 years of age. Finally, epilepsy was more prevalent in males, especially the white color and with an average age of 8 years [6].

A multicenter study conducted in the US and Canada, between 2005 and 2009, collected data from children with chronic kidney disease and found that children and adolescents from low-income families are more likely to be black race, hispanic ethnicity and female compared to high-income children afflicted with the same disease [8].

From another perspective, a study of the aboriginal population, conducted between 2002 and 2004 in Australia, aiming to determine the risk of chronic kidney disease in childhood, it was found that the prevalence of kidney disease in the terminal stage in the areas collected, were 1170 cases per million population native, compared with 740 cases per million population of non-native. Of the children, had 1,248 aboriginal and 1,018 non-natives, these 51\% were male, and the mean age was 8.9 years [9].

A study conducted in Puerto Rico, asthma was a disease target for researchers. The data revealed that there were 3,878,000 young people between the years 2001-2003, with asthma, it has been found 111 deaths in that period. Estimates of avera- ge annual prevalence was approximately 45\% higher for black children than for white as well as the average annual estimates of asthma attacks. The study also revealed that poor and young people living in urban areas have higher rates of asthma and showed the most severe forms of the disease, moreover, were less likely to receive high quality medical care and to use medicines appropriately [10].

In Brazil, a search of adolescents with asthma, found that of 114 adolescents interviewed, most had less than 15 years old and were male gender [11]. It can be observed that the results of a survey conducted in Australia, came to corroborate the data of the Brazilian study and shows that asthma has a higher incidence in males than in females. Noteworthy is also the global prevalence of asthma in 4,611 children aged 5 to 15 years with $18.6 \%$ in the study population during the period 2002 to 2007 [12].

Also as regards chronic diseases, there is the Diabetes Mellitus Type I, which was addressed as the object of a study in Itabuna (Bahia-Brazil), where it was noted the influence of sociodemographic factors on the children quality of life with the referred disease. The findings showed that the factors that influence the worsening of quality of life are: female, adult, diagnostic time or equal to ten years and low family income. As for the factors that does not intervene significantly in quality of life are: education, occupation, ethnicity, body mass index, number of daily insulin injections and monitoring of blood glucose profile [13].

Another study, which diabetes was discussed, held in Goiania (Goias-Brazil), looked for a relation between the demographics of 84 adolescents with the disease and glycemic control. Thus, it was found that there was no significant difference between genders and age averages of groups of adequate glycemic control and inadequate. The author argues that has not been established relation between age at diagnosis and glycemic con- 
trol, but it is known that the incidence of diabetes is increasing especially in younger age groups, in the entire world. In the study, it was observed that adolescents were diagnosed with average age less than 10 years old [14].

However, another study with children and adolescents with diabetes in Poland showed that there were differences between age groups in the incidence of diabetes decompensated, where the highest rate was between 13 and 18 years old. The author seeks to justify stating that this group is affected by several factors such as adolescence, physical and hormonal changes [15].

In Florida, the barriers were also observed to health care for young ( $<20$ years old) with diabetes. That said non-hispanic black youth were significantly more likely to lack of regular medical care compared to non-hispanic white youth. It analyzed the racial and ethnic disparities were constantly associated with barriers to access to care in young people with diabetes type [16].

In research conducted in California (USA), from 2001 to 2005, authors tried to analyze the demographic variables of children with tumors. Then carried out a comparative study showing that in almost all age groups, the malignancy rate was higher in male children and the girls were most affected of benign tumors. With one caveat for teens, where the percentage of benign tumors in males was higher. The study also showed that hispanic children under 5 years had proportionately higher incidence of tumors. While in non-hispanic white teens, the rate was higher. From 5 to 9 years old, the hispanic children were more affected by malignant tumors, while the non-hispanic white children were most affected of benign tumors [17].

From another perspective, a study in Goiânia (Goias-Brazil), with adolescents with diabetes, to the principal caregiver profile, pointed out that this group is mainly composed of the mothers [14]. A literature review conducted in order to compare family functioning in families with children and ado- lescents with five different chronic diseases (cystic fibrosis, sickle cell anemia, epilepsy, inflammatory bowel disease and obesity), also found that most the main caregivers are mothers (81\% cystic fibrosis, $92 \%$ were obese, $84 \%$ sickle cell anemia, $91 \%$ inflammatory bowel disease, $81 \%$ epilepsy). Moreover, in all diseases, except in obesity (62\% single), the number of single caregivers was considered low [6].

In Nigeria, an article discussed the risk of otitis media and the relation with the family profile, the authors reported that the risk factors in children with chronic otitis media were higher in children with a large number of residents in the same house and still a family with more than 5 children [18].

\section{Relations between social and economic variables (income, occupation, data on family, education and primary caregiver) and chronic disease in children and adolescents}

Studies linking the variables family income, occupation of family, education levels and data on the primary caregiver of children and adolescents with chronic disease, are common in the literature. However, these studies address the issue as secondary. Still, it is essential to consider the social and economic variables in the theme of chronic disease as it interfere directly or indirectly in the success of care. It is considered income a good measure of material resources, but is not a constant gauge, since it is subject to factors such as age, education, family size, cost of living and the number of people who contribute to that income [19].

On the characterization of income and other factors, research on chronic kidney disease found that children and adolescents from families with low income and low maternal education have higher rates of abnormal history at birth, moreover, need more service private health. In these families was observed a higher proportion of children and adolescents with at least one comorbidity, besides renal disease. 
However, for many comorbidities there were no differences by income categories, a reassuring finding in this high-risk population [8].

In the same study, it was described that over the history of abnormal birth (preterm birth, small for gestational age or low birth weight), was more common among families of low and middle income in relation to the category of higher income $34 \%$ and $32 \%$ vs. $21 \%$; $P=0.01$ ), to investigate comorbidities at baseline, estimates suggest slightly higher proportion of persons affected by more than one disease or chronic condition among families with lower levels of income, although these associations were not significant.

In what concerns the family income and quality of life of 114 adolescents with asthma treated at a clinic for pulmonology, it was found that $21.1 \%$ belonged to the social class B (gross monthly household income between US \$1,269.00 and US \$ $2,187.00$ ) and $61.4 \%$ C (gross monthly household income between US $\$ 465.00$ and US \$763.00) according to the criteria of the Brazilian Association of Business Research (ABEP), however, not present study found a correlation between socioeconomic variables and quality of life in patients with asthma, and the fact that socioeconomic variables was hampered by the fact that the participants belonged to economic classes B and C (80.7\%) [11].

Similarly, another study in South Australia with 4,611 children aged 5 to 15 years old, going to school, the results also indicated that asthma was significantly less likely to occur in children living in households where income was US\$ 80,000 or higher [12].

Still about asthma, other survey of children aged 9 and 18 (37 children with asthma and 39 healthy children), it was observed that in children with asthma, a lower socioeconomic status was associated with increased IL-5 and IL-13 and higher eosinophil count $(P<.05)$, and the author still managed to associate psychological stress with socioeconomic status in the same study [20].
Another study conducted at the Clinic of Endocrinology of the Hospital of the UFG and General Hospital of Goiania, with 84 adolescents with diabetes type 1, was found that $22.5 \%$ of adolescents had occupation and already working to supplement the family income. Moreover, while the per capita monthly income do not have significant influence on glycemic control of these, the prevalence of $78 \%$ of patients with income below half the minimum wage that had metabolic inadequacy suggests that financial constraints may be reinforcing this context [13].

Still with regard to diabetes, other study involved 34 diabetes in children and adolescents showed that the per capita family income was $0.70 \pm 0.56$ minimum wages [14]; these findings may contribute to the evidence that low family income it can be a trigger factor for the work of young adolescents, thus influencing the metabolic control.

In 2008, the city of Campinas (São Paulo-Brazil), were collected data 929 adolescents with 10 to 19 years old and it was observed that $19.75 \%$ were working, but could not find statistical association of chronic diseases and health problems the variables family income [3].

The United States and Canada conducted a survey of 11,447 patients younger than 18 years and found that those with low incomes have less access to medical appointments. Pulmonary exacerbations requiring antibiotics $\mathrm{VI}$ are most often diagnosed and treated in patients with lower status of family income and maternal education. However, there are few comparative studies on family income in patients with cystic fibrosis.

California (USA), a study of tumors in children, showed that in children under 5 years, the number of cases was higher when the socioeconomic level was lower. In children aged 5 to 9 years, there are more malignant cases and uncertain behavior at lower socioeconomic levels, while in children with higher income, there was a higher incidence of benign tumors. For adolescents age groups 10 
to 14 and 15 to 19 , all malignant cases were in high socioeconomic status. In the 10 to 14 years old range, benign cases were of high socioeconomic status, while the doubtful were low. The opposite was observed in the age group 15 to 19 years, in the uncertain cases were high-level, while the benign cases were higher in low [17].

In Nigeria, a study of a sample of 189 participants diagnosed with otitis media, showed that low socioeconomic class predominated with 153 cases (81\%), moreover, been seen that the same percentage living in households with more than 10 persons. There was also that 79 participants (42\%) belong to families with more than five children. These factors were considered at risk for the disease studied ${ }^{1} \otimes$. The study also reported that the total sample, 117 children (62\%) attended the nursery, however, it was not found significant relationship with school attendance and chronic infection [18].

Access to health care provided by the state, was also evaluated in a study. The result showed that access to public service reduced the likelihood of families to face barriers in access to care and high spending on treatment [16].

Regarding education of the child/adolescent, a literature review has shown that young people with asthma are more likely to abstain school and a lower income. This is because the symptoms, the need to attend medical consultations, hospitalization, care to avoid environmental factors at school, deprivation consequent sleep the night attacks, comorbidity (eg, respiratory diseases) associated with increased susceptibility between other [10].

The level of parental education was also highlighted in the findings of this review, some authors [3] report in the results of their research that this variable did not influence the prevalence of chronic diseases or quality of life [13].

Unlike, Stefanowicz, compared groups of children and adolescents with diabetes type I compensated and decompensated. In this study, it was found that the group with the controlled glycemic rate, parents had a higher education level $(20.6 \%$ of mothers and $22.2 \%$ of fathers had completed high school), compared to those who were uncontrolled $(7.7 \%$ of mothers and parents to complete high school) [15]. Another study involving diabetes type I, adds that parents/caregivers with lower level of education to high school, reported more problems with daily care than those with higher education. In addition, caregivers with higher education were less likely to report communication problems [16].

Similar findings were observed in the control of cystic fibrosis [19]. Children with mothers with higher levels of education have a greater number of outpatient visits; less pulmonary exacerbations and, consequently, less need for potent antibiotics; greater adherence to treatment and greater request prescription vitamins. Thus, these studies indicate that education level is closely associated with the control of the disease. In addition, these factors influence the child's/ adolescent's quality of life in disease management ability and family functioning.

\section{Conclusion}

Given the above, we conclude that there is evidence on the relationship of the socioeconomic profile of children and adolescents with chronic disease, having been identified in scientific production.

According to the studies found, it was possible to trace the socio-demographic profile of children and adolescents with $C D$, based on five variables: sex, age, race, income and education. In general, with regard to sex, the male predominance is observed, but the difference between boys and girls was low. Thus, females predominated only in cases of cystic fibrosis, type 1 diabetes and chronic renal failure. Regarding age, the studies showed that most children and adolescents with CD are included in the range between 10 and 15 years, affected mainly by kidney disease, asthma and diabetes type I. It was also observed that children affected by obesity and epilepsy had lower age than 10 years. The 
race, in turn, is a condition that depends on chronic disease. The profile follows composed of mostly white, except for genetic nature of diseases, such as sickle cell disease with the highest black population. According to studies, most families are low income, and asthma, DM I, chronic otitis media, obesity, sickle cell anemia and epilepsy, the most common diseases in this class. Families with better financial conditions, had cystic fibrosis and intestinal diseases like more present conditions. Only psychological problems, was more present in high-income families. With regard to the variable education, few articles dealt with this issue. Those who have pointed out, found that most of the children and adolescents with CD attending day care or school, and had not completed elementary school. An important aspect, however, addressed in a single study, was the education of the parents, whose characteristic was completed higher education, most.

According to the summary of articles, we observed that draw or describe the socioeconomic profile of children and adolescents with chronic diseases is still somewhat hampered by a lack of understanding of this objective as a key issue for research. Consequently, this profile appears in studies as secondary to a particular disease. Thus, it can be said that this profile was quite varied depending on the chronic disease, study site, sample and even the length of time that the survey was conducted.

In addition, based on articles found, it is observed that the studies bring a low representation of many chronic diseases of children and adolescents worldwide, and asthma and diabetes mellitus the most cited and studied diseases.

One aspect rarely addressed in the studies was the demographic profile of family of children and adolescents with chronic diseases. This profile is correlated with the factors involved in the family dwelling, with regard mainly to urbanization, sanitation, number of residents, among others. These aspects also influence the development of this population, but it was a given rarely addressed by the articles.
However, the authors included in the review agree on the fact that the socioeconomic variable family reaches the child or adolescent patient at some point, either in the presence of comorbidities, quality of life in general or in access to health services.

\section{Acknowledges}

The authors acknowledge the financial support of CNPq , universal notice Notice 01/2014 (No. Process: 448716 / 2014-3 ) in this study.

\section{References}

1. Alves JED. A transição demográfica e a janela de oportunidade. Instituto Fernand Braudel de Economia Mundial. 2008. São Paulo. Available from: http://www.braudel.org.br/pesquisas/ pdf/transicao demografica.pdf

2. Mendes EV. O cuidado das condições crônicas na atenção primária à saúde: o imperativo da consolidação da estratégia da saúde da família. Organização Pan-Americana da Saúde. Organização Mundial da Saúde. 1 ed. 2012. Brasília-DF. Available from: $\quad$ http://apsredes.org/site2012/wp-content/uploads/ downloads/2012/04/RedesdeAtencaocondicoescronicas.pdf

3. Braz M, Barros Filho AA, Barros MBA. Saúde dos adolescentes: um estudo de base populacional em Campinas, São Paulo, Brasil. Cad. Saúde Pública. 2013 Set; 29(9):1877-1888. Available from: http://unicamp.sibi.usp.br/bitstream/handle/SBURI/24755/ s0102-311X2013000900026.pdf?sequence $=1$

4. Malta DC, Cezário AC, Moura L, Morais Neto OL, Silva JB. A construção da vigilância e prevenção das doenças crônicas não transmissíveis no contexto do Sistema Único de Saúde. Epidemiologia e Serviços de Saúde. 2006; 15(1): 47-65. Available from: http://scielo.iec.pa.gov.br/pdf/ess/v15n3/v15n3a06.pdf

5. Ferreira PRA. Doença crônica na criança: importância do núcleo familiar. Psicologia PT. 2013. Portugal. Available from: http:// www.psicologia.pt/artigos/textos/TL0324.pdf

6. Herzer M, Godwala N, Hommel KA, Driscoll K, Mitchell M, Crosby LE et al. Family Functioning in the Context of Pediatric Chronic Conditions. J Dev Behav Pediatr. 2010 Jan; 31(1):26. Available from: http://www.ncbi.nlm.nih.gov/pmc/articles/ PMC2821736/

7. Zashikhina A, Hagglof B. Family functioning and juvenile chronic physical illness in Northern Russia. Acta Paediatrica. 2009; 98: 355-360. Available from: http://europepmc.org/abstract/ $\underline{\mathrm{med} / 19006528}$

8. Hidalgo G, Ng DK, Mins MM, Minnick, Hansen TB, Warady BA, Furth S. Income level and kidney disease severity and progression among children and adolescents with CKD: a report from the Chronic Kidney Disease in Children (CKiD) Study. [Internet]. 2015 [cited 2015 Mar. 27]; Am J Kidney Dis. 2013 Dec; 62(6): 1087-94. Available from: http://www.ncbi.nlm.nih.gov/pmc/ articles/PMC3840111/. 
9. L Haysom et al. Markers of CKD Aboriginal and non-Aboriginal children. Early chronic kidney disease in Aboriginal and nonAboriginal Australian children: remoteness, socioeconomic disadvantage or race?. Kidney International (2007) 71: 787-794. Available from: http://www.sciencedirect.com/science/article/ pii/S0085253815524514

10. Basch CE. Asthma and the Achievement Gap Among Urban Minority Youth. Journal of School Health. 2011; 81(10): 606613. Available from: http://onlinelibrary.wiley.com/doi/10.1111/ j.1746-1561.2011.00634.x/pdf

11. Amaral LM, Moratelli L, Palma PV, Leite ICG. The quality of life of Brazilian adolescents with asthma: associated clinical and sociodemographic factors. J Asthma, [Internet]. 2014 [cited 2015 dez. 10]; 51(6): 660-6. Available from: http://informahealthcare. com/jas.

12. Collins JE, Gill TK, Chittleborough CR, Martin AJ, Taylor AW, Winefield H. Mental, emotional, and social problems among school children with asthma. J Asthma. 2008 Aug; 45(6):489-93. Available from: http://www.tandfonline.com/doi/ full/10.1080/02770900802074802

13. Araújo AF, Souza MEA, Menezes CA. Qualidade de vida e aspectos socioeconômicos em diabéticos tipo 1. Arq Bras Endocrinol Metab. [Internet]. 2008 Oct [cited 2016 mar 07]; 52(7): 1124-1130. Available from: http://www.scielo.br/scielo.php?script=sci arttext\&pid=\$000427302008000700008\&lng=en. $\quad$ http://dx.doi.org/10.1590/ S0004-27302008000700008.

14. Marques RMB, Fornés NS, Stringhini MLF. Socioeconomic, demographic, nutritional, and physical activity factors in the glycemic control of adolescents with type 1 diabetes mellitus. Arq Bras Endocrinol Metab. [Internet]. 2011 [cited 2015 mar 28]; 2011; 55(3): 194-202. Available from: http://www.scielo.br/scielo. php?script=sci arttext\&pid=S0004-27302011000300004.

15. Stefanowicz A, Birkholz D, Mysliwiec M. Analysis of the impact of environmental and social factors, with a particular emphasis on education, on the level of metabolic control in type 1 diabetes in children. Endokrynolgia Polska/Polish Journal of Endocrynology. 2012: 63(1): 34-41. Available from: http://www. ncbi.nlm.nih.gov/pubmed/22378096

16. Valenzuela JM, Seid M, Waitzfelder B, Anderson AM, Beavers DP, Dabelea DM, et al. Silverstein and WFB Prevalence of and Disparities in Barriers to Care Experienced by Youth with Type 1 Diabetes. J Pediatr. 2014 Jun; 164(6): 1369-1375. Available from: http://www.sciencedirect.com/science/article/ pii/S0022347614000638

17. Brown M, Schrot R, Bauer K, Dodge J. Incidence of first primary central nervous system tumors in California, 2001-2005: children, adolescents and teens. J Neurooncol. 2009 Sep; 94(2):263-73. Available from: http://link.springer.com/article/10.1007/s11060$\underline{009-9864-x}$
18. Akeem O. Lasisi, Fatai A. Olaniyan, Sufyan A. Muibi, Ismail A. Azeez, Kehinde G. Abdulwasiu, Taiwo J. Lasisi, Zainab O. Imam, Taofeeq O. Yekinni, Oladapo Olayemi. Clinical and demographic risk factors associated with chronic suppurative otitis media. International Journal of Pediatric Otorhinolaryngology. 2007; 71: 1549-1554. Available from: http://www.ijporlonline.com/ article/S0165-5876(07)00256-X/pdf

19. Schechter MS, McColley SA, Silva S, Haselkorn T, Konstan MW, Wagener JS. Association of Socioeconomic Status with the Use of Chronic Therapies and Healthcare Utilization in Children with Cystic Fibrosis. J Pediatr. 2009; 155 (5): 634-9. Available from: http://www.ncbi.nlm.nih.gov/pmc/articles/PMC4161122/

20. Chen $E$, et al. Socioeconomic status and inflammatory processes in childhood asthma: The role of psychological stress. J Allergy Clin Immunol. 2006; 117(5):1014-20. Available from: http://www.jacionline.org/article/S0091-6749(06)00290-9/pdf

21. Gerson AC, Wentz A, Abraham AG, Mendley SR, Hooper SR, Butler RW, Gipson DS, Lande MB, Shinnar S, Moxey-Mims MM, Warady BA. Health-related quality of life of children with mild to moderate chronic kidney disease. Pediatrics. 2010 Feb 1; 125(2):e349-57.

22. Shone LP, Conn KM, Sanders L, Halterman JS. The role of parent health literacy among urban children with persistent asthma. Patient education and counseling. 2009 Jun 30;75(3):368-75.
Publish in International Archives of Medicine

International Archives of Medicine is an open access journal publishing articles encompassing all aspects of medical science and clinical practice. IAM is considered a megajournal with independent sections on all areas of medicine. IAM is a really international journal with authors and board members from all around the world. The journal is widely indexed and classified Q1 in category Medicine. 